\title{
Penyuluhan Penegakkan Hukum di Lingkungan Sekolah
}

\author{
Yulita Pujilestari ${ }^{\mathrm{a}, 1}$, Endang Prastini ${ }^{\mathrm{b}, 2}$ Amelia Haryanti $\mathrm{i}^{\mathrm{c}, 3}$ \\ ${ }^{a, b, c}$ Fakultas Keguruan dan Ilmu Pendidikan, Universitas Pamulang \\ ${ }^{1}$ yulitapujilestari13@gmail.com \\ *Korespodensi Penulis
}

Naskah diterima: 10 Maret 2019, direvisi: 25 Maret 2019, disetujui: 29 Maret 2019

\begin{abstract}
Abstrak
Hukum merupakan aturan tentang tingkah laku manusia yang dipatuhi oleh masyarakat, saat ini pelanggaran hukum di kalangan masyarakat sering dilakukan. Sebagai upaya meminimalisir pelanggaran hukum di masyarakat, perlu diadakan penyuluhan tentang penegakkan hukum di lingkungan sekolah. Kegiatan pengabdian bertujuan untuk membantu dalam menumbuhkan rasa tanggungjawab dalam menegakkan hukum dalam kehidupan peserta didik sehari-hari. Pada pengabdian ini menggunakan metode penyuluhan dan penyadaran. Hasil pengabdian masyarakat yaitu adanya peningkatan kesadaran peserta didik untuk menegakkan hukum baik di lingkungan sekolah maupun rumah. Saran kepada pihak sekolah agar melibatkan peserta didik secara langsung untuk menegakan aturan hukum di sekolah maupun masyarakat.
\end{abstract}

Kata kunci: Penegakkan; Hukum; Sekolah

\section{Abstract}

Law is the rule of human behavior that is adhered to by society, nowadays violations of the law among the community is often done. In an effort to minimize legal violations in the community, there is a need for counseling on law enforcement in the school environment. Devotion activities aim to assist in cultivating a sense of responsibility in enforcing the law in daily student life. In this devotion, using counseling methods and awareness. The results of community devotion are increased awareness of students to uphold the law both in school and home environment. Advice to the school to involve students directly to enforce the rules of law in schools and communities.

Keywords: Enforcement; Law; School 


\section{PENDAHULUAN}

Indonesia merupakan negara berdasarkan hukum oleh karenanya bahwa hukum wajib ditegakkan oleh pemerintah dan masyarakat. Hukum mempunyai sanksi yang tegas, bersifat memaksa, dan dibuat oleh pejabat yang memiliki kewenangan membuatnya. Seiring dengan tuntutan masyarakat, maka hukum terus berkembang sesuai dengan kebutuhan masyarakat saat ini. Hukum telah diatur di dalam berbagai peraturan yang berlaku di Indonesia, salah satu pedoman hukum yang termaktub dalam Undang-Undang Dasar 1945. Undang-Undang merupakan seperangkat aturan yang dikumpulkan dengan teratur terkodifikasi dimana sifatnya mengikat warga negara. Hukum juga tentang aturan untuk setiap tindakan setiap manusia didalam tatanan bermasyarakat. Dalam implementasinya bisa dipaksakan untuk tujuan mendapatkan keadilan.

Hukum ialah tentang peraturan dan semua dasar yang mengatur kehidupan sosial serta memiliki tujuan menjaga keraturan serta mencakup banyak lembaga serta proses dalam menciptakan aturan hukum menjadi hal nyata di masyarakat. Hukum juga merupakan norma berkaitan tentang hal sesuatu yang benar serta salah, dibuat kemudian diakui oleh pemerintah, baik dalam bentuk peraturan yang tertulis maupun tidak, mengikat dan sesuai dengan yang dibutuhkan masyarakat secara keseluruhan, serta dengan sanksi bagi mereka yang melanggar norma.

Dapat disimpulkan bahwa hukum adalah sistem yang paling penting dalam mewujudkan serangkaian kebijakan dan kekuasaan institusional dari bentuk penyelewengan penguasaan dalam politik, ekonomi serta masyarakat dalam banyak cara serta tindakan, sebagai penghubung utama didalam hubungan masyarakat antara publik dan pidana.

Demikianlah menjadi warga Negara Indonesia yang patuh pada hukum, warga negara harus memahami garis-garis penegakan hukum yang sebagaimana mestinya. Sehingga kita bisa menegakkan hukum di negara kita dengan baik. Secara formal, hukum dapat diartikan sebagai suatu sistem yang sangat diutamakan dalam 
mengimplementasikan kumpulan kekuatan kelembagaan dari bentuk penyimpangan penguasaan di bidang ekonomi, politik serta masyarakat.

Hukum pidana mengatur berbagai pelanggaran yang terjadi dalam kehidupan masyarakat yang tertuang dalam konstitusi perundangan-undangan. Hukum memiliki tujuan yang komprehensif karena mengatur interaksi kehidupan manusia untuk menciptakan kedamaian, kenyamanan, ketertiban, dan kebahagiaan dalam tatanan kehidupan sosial. Hukum diharapkan dapat ditegakkan secara adil tanpa membedakan status sosial masyarakat sesuai dengan amanat Undang-Undang Dasar 1945 tentang "keadilan sosial bagi seluruh rakyat Indonesia".

Hukum bertujuan adalah untuk dapat mengarahkan tatanan kehidupan manusia dengan adil dan damai. Tujuan dari aturan ini adalah untuk membuat suasana aman juga tertib di dalam kehidupan masyarakat. Hukum mempunyai tujuan kearah keadilan bagi seluruh rakyat Indonesia. Hukum diharapkan dapat melindungi kepentingan setiap manusia sehingga berbagai kepentingan masing-masing manusia tidak dapat diganggu. Lebih jelas lagi tujuan dari tatanan aturan ini adalah untuk memastikan kepastian hukum dalam suatu komunitas, dan untuk melindungi dan mencegah setiap orang dalam suatu masyarakat untuk menuntut diri mereka sendiri.

Hukum bertujuan untuk memanipulasi masyarakat, yang berarti bahwa hukum sebagai alat untuk perubahan sosial, pada dasarnya hukum di sini sebagai wadah atau alat yang diperuntukan merubah warga masyarakat mengarah kearah yang lebih baik, baik secara individu ataupun dalam kehidupan bermasyarakat.

Tujuan hukum adalah untuk meningkatkan kesejahteraan publik atau kepentingan publik, yaitu kesejahteraan atau kepentingan semua anggota warga. Tujuan hukum kemudian membenahi semua hubungan kehidupan manusia secara damai. Selain itu, undang-undang ini bertujuan untuk melindungi manusia baik secara aktif dalam mengupayakan untuk menciptakan kondisi di yang aman di masyarakat sehingga menekan adanya perilaku penyimpangan dan penyalahgunaan hak secara tidak adil.

Berdasarkan UUD 1945 yang berbunyi "Negara Indonesia ialah negara berdasarkan hukum”. Maka, sebagai negara hukum Negara berhak untuk menegakkan hukum, membuat berbagai aturan atau kebijakan hukum di 
Indonesia. Sehingga setiap warga negara dapat mematuhi aturan hukum yang mengikat dan memaksa.

\section{Lembaga penegak hukum} diharapkan memberikan keadilan yang merata. Namun, kenyataannya masih terdapat kelalaian dalam menegakkan hukum di negara Indonesia. Serta terdapat banyak ketidakadilan bagi warganya dalam menerapkan aturan yang diterapkan di Indonesia. Dampak kelalaian yang telah terjadi diantaranya banyak peraturan hukum yang di langgar, penegakkan hukum yang berjalan tidak adil, dan bahkan pelakunya dapat terlepas dari jeratan hukum. Permasalahan tersebut sangat tidak baik bagi generasi penerus bangsa selanjutnya. Dengan demikian, penegakan hukum harus dilaksanakan dengan adil serta wajib ditaati oleh seluruh warga negara Indonesia.

Penegakan hukum harus selalu diingat dan dijalankan, sehingga dapat tercipta keadilan bagi seluruh rakyat Indonesia. Banyak pelanggaran terkait dengan hukum, sehingga perlu adanya penyuluhan terkait dengan penegakkan hukum kepada masyarakat. Jika masyarakat teredukasi dengan baik, maka diharapkan penegakkan hukum dapat berjalan dengan optimal.
Penyuluhan tentang hukum sebagai upaya yang dilakukan secara sadar untuk mengendalikan perilaku orang-orang dalam kehidupan masyarakat sehingga aturan-aturan hidup yang berlaku dalam masyarakat dapat ditaati dengan baik. Penyuluhan Hukum mengusahakan seseorang untuk mengetahui sanksi hukum jika mereka melanggarnya. Penyuluhan dapat bertujuan untuk menumbuhkan kesadaran akan hukum bagi setiap warga negara sehingga ia akan menjadi lebih sadar, lebih memahami, dan dapat menerapkan dengan konsisten aturanaturan hukum yang berlaku di Indonesia.

Salah satu sosialisasi penegakkan hukum yang penting dimulai dari lingkungan keluarga, sejak kecil proses penyuluhan dapat diterapkan kepada anak-anak. Di lingkungan keluarga inilah tempat sosialisasi awal penanaman prinsip-prinsip hidup yang telah disetujui oleh masyarakat setempat, seperti saling menyayangi, menghormati, cinta kasih dan menghargai. Keluarga tempat sosialisasi hukum yang efektif sebelum seorang anak terjun secara langsung menjadi anggota masyarakat. Orangtua menjadi pigur yang sangat penting dalam memberikan contoh penegakkan hukum di Indonesia. Kemudian dari lingkungan keluarga akan dilanjutkan ke lingkungan 
sekolah dan masyarakat luar pada umumnya.

Pada saat seseorang anak sudah mulai bertambah menjadi dewasa, maka pada saat itu juga seorang individu baru mulai diperkenalkan dengan aturan dan prinsip-prinsip hukum negara yang mereka ketahui lewat pendidikan hukum yang diterimanya baik secara formal maupun informal. Lewat pendidikan inilah seseorang teredukasi dengan baik mengenai aturan-aturan hukum yang berlaku di negaranya, sehingga diharapkan seseorang tersebut dapat menjadi warga negara yang baik. Bahkan sebelum menginjak usia dewasa seseorang teah disosialisasikan tentang hukum di mulai dari lingkungan keluarga, lingkungan sekolah dan masyarakat. Pemahaman terhadap hukum dapat dilakukan dengan konseling hukum. Konseling hukum berarti upaya sadar yang dilakukan seseorang untuk mematuhi aturan-aturan hukum yang berlaku.

Ketika seorang individu belajar untuk memahami kaidah hukum yang berlaku di negaranya, sehingga dengan kesadaran diri seseorang tersebut dapat meninggalkan kebiasaan-kebiasan lama yang tidak baik bahkan perilaku yang melanggar hukum, dengan begitu akan muncul dengan sendirinya kesadaran hukum dalam diri seseorang. Dengan demikian, konseling hukum sangat diyakini mampu mengubah seseorang dari situasi non-sosial atau perilaku yang menyimpang menjadi makhluk sosial yang ingin memperhatikan kepentingan orang lain dan tidak mengulangi perilaku penyimpangan tersebut.

Sebagaimana dinyatakan di atas, dalam konseling hukum menumbuhkan kesadaran hukum dalam diri seseorang, bahwa dengan kesadaran ini akan membuat seseorang secara sukarela menyesuaikan semua perilaku berperilaku dengan undang-undang. Dalam upaya kesadaran adalah mengembangkan mekanisme kontrol diri atas perilaku yang ia lakukan.

Penyelenggaraan hukum dapat juga diartikan sebagai penegakkan hukum oleh aparat hukum yang berwenang dan penegakkan hukum yang dilakukan oleh setiap masyarakat. Penegakkan hukum dikemukan Soekanto (1983: 5) merupakan "sesuatu kegiatan yang dapat menyelaraskan hubungan nilai-nilai yang terjabarkan dalam kaidah-kaidah serta asas-asas dan sikap tindak sebagai rangkaian penjabaran nilai tahap akhir untuk menciptakan, memelihara, dan mempertahankan kedamaian dalam pergaulan hidup". 
Penegakan hukum tidak sematamata hanya dimaksudkan dengan membuat peraturan, mengimplementasikan undang-undang tetapi terkait dengan faktor-faktor lain, termasuk faktor hukum itu sendiri, faktor penegakan hukum, serta faktor pendukung fasilitas penegakan hukum dan faktor masyarakat. Pada penegakan hukum melalui upaya menumbuhkan kesadaran akan cenderung menuju pada mekanisme "kontrol sosial" yang merupakan kesadaran batin terhadap hukum.

Munculnya kesadaran hukum batin dipandang sebagai sangat penting bagi penegakan hukum di masa depan karena dalam waktu yang lama hukum tidak akan mungkin jika hanya bergantung pada mekanisme sanksi kontrol sosial yang hanya bekerja dari luar kesadaran. Untuk alasan ini, hukum negara harus ditegakkan melalui upaya dan proses meningkatkan kesadaran hukum di antara orang-orang, yang dapat dilakukan melalui konseling hukum.

Masalah utama dalam penegakan hukum disebabkan oleh berbagai faktor yang dapat mempengaruhi diantaranya: faktor lingkungan, faktor budaya, faktor penegak hukum, faktor masyarakat, faktor sarana dan fasilitas penegak hukum, serta faktor lainnya. Faktorfaktor tersebut merupakan tolok ukur efektivitas penegakan hukum di Indonesia. Sebagai warga negara yang baik tentunya masalah penegakkan hukum perlu dipelajari dan ditaati bersama, salah satu agen sosialisasi penegakkan hukum yaitu lembaga pendidikan.

Sekolah sebagai lembaga pendidikan memainkan peran penting dalam memberikan pembelajaran tentang hukum di Indonesia, sehingga dengan adanya pembelajaran tersebut dapat mengedukasi generasi muda untuk mematuhi aturan hukum yang berlaku di lingkungan sekolah, keluarga, maupun masyarakat.

Melahirkan generasi sadar akan hukum perlu diwujudkan secara intensif bukan hanya pada tataran konsep dalam pelajaran di sekolah saja, seperti yang terdapat dalam mata pelajaran Pendidikan Kewarganegaraan. Tetapi implementasi penegakkan hukum diberbagai bidang studi dan dilakukan oleh para guru yang dapat menjadi panutan bagi peserta didik di sekolah. Jika kesadaran tersebut telah tumbuh dalam diri peserta didik maka akan menjadi alat kontrol diri untuk tidak melakukan perbuatan yang melanggar hukum. 
Berdasarkan latar belakang tersebut, kami dari Tim Program Pengabdian Masyarakat (PKM) Universitas Pamulang (UNPAM) yang berjumlah 8 dosen akan melakukan penyuluhan hukum terhadap siswa SMAN 3 Kota Tangerang Selatan dengan judul PKM: "Penyuluhan Penegakkan Hukum di Lingkungan Sekolah".

\section{METODE}

Universitas Pamulang (UNPAM) merupakan kampus yang berdiri di bawah naungan Yayasan Sasmita Jaya yang beralamat di jalan Surya Kencana No.1 pamulang tangerang selatan dengan mengemban visi "Bermutu dalam pengembangan pendidikan, penelitian, dan pengabdian terjangkau seluruh lapisan masyarakat, berlandaskan Ridha Tuhan Yang Maha Esa”.

UNPAM membuka diri untuk melakukan berbagai kolaborasi dengan berbagai pihak dalam rangka pengembangan ilmu pengetahuan, institusi, teknologi dan seni dalam rangka implementasi Tri Dharma Pendidikan Tinggi yaitu Pendidikan, Penelitian dan Pengabdian.

Dalam mengemban tugas untuk mengabdikan diri kepada masyarakat, maka Tim Pengabdian Kepada Masyarakat (PKM) bermaksud mengadakan penyuluhan tentang penegakkan hukum di lingkungan sekolah, yang diadakan di SMA Negeri 3 Kota Tangerang Selatan. Pemilihan tempat pengabdian masyarakat di SMA Negeri 3 Kota Tangerang Selatan tersebut karena lokasi sekolah yang dekat dengan Universitas Pamulang masih dalam area Tangerang Selatan, sehingga diharapkan Universitas Pamulang dapat bersinergi bagi masyarakat sekitar terutama bagi lembaga pendidikan di sekitar Universitas Pamulang. Sudah selayaknya kehadiran perguruan tinggi agar dapat benar-benar dirasakan manfaatnya oleh masyarakat terutama masyarakat sekitar Universitas Pamulang.

Program pengabdian ini tersusun berdasarkan hasil survey pendahuluan oleh Tim PKM yang berjumlah 8 dosen Program Studi Pendidikan Pancasila dan Kewarganegaraan Fakultas Keguruan dan Ilmu Pendidikan. Tim dosen PKM melakukan wawancara kepada siswa terkait dengan pengetahuan tentang penegakkan hukum di Indonesia.

Tujuan umum dari kegiatan pengabdian kepada masyarakat ini adalah membantu untuk menumbuhkan rasa tanggungjawab dalam menegakkan 
hukum nasional, membantu agar siswa SMA dapat memahami dampak hukum jika dilanggar, membantu mensosialisasikan sistem hukum Nasional di Indonesia kepada peserta didik.

Dalam pengabdian kepada mayarakat ini adapun Metode yang akan digunakan adalah melalui kegiatan pemberian penyuluhan dan penyadaran berupa pendampingan. Hal mendasar yang ditawarkan untuk ikut memecahkan masalah adalah melalui kegiatan penyuluhan kepada siswa SMAN 3 Kota Tangerang Selatan yang dikemas dengan nama kegiatan "Penyuluhan Penegakkan Hukum di Lingkungan Sekolah”.

\section{HASIL DAN PEMBAHASAN}

Pra Kegiatan Persetujuan proposal pengabdian masyarakat pada kampus Universitas Pamulang dan SMA Negeri 3 kota Tangerang Selatan, guna membekali bagaimana menjadi pelaksana hukum. Para siswa dan siswi menjadi terbuka dan mampu mengatur kehidupan teratur mereka secara mandri dan bermanfaat untuk orang lain.

Persiapan yang dilakukan adalah segala hal yang terkait dengan materi,

Materi yang diberikan adalah tentang ditegakkanya hukum, proses melaksanakan dalam upaya untuk menegakkan atau berbagai peralatan untuk pengabdian. Hasil persiapan tersebut dimaksudkan agar materi tersampaikan dengan dan mudah dimengerti serta dipahami oleh para siswa siswi SMAN 3 kota tangsel Pamulang. Berikut skema Pengabdian Kepada Masyarakat :
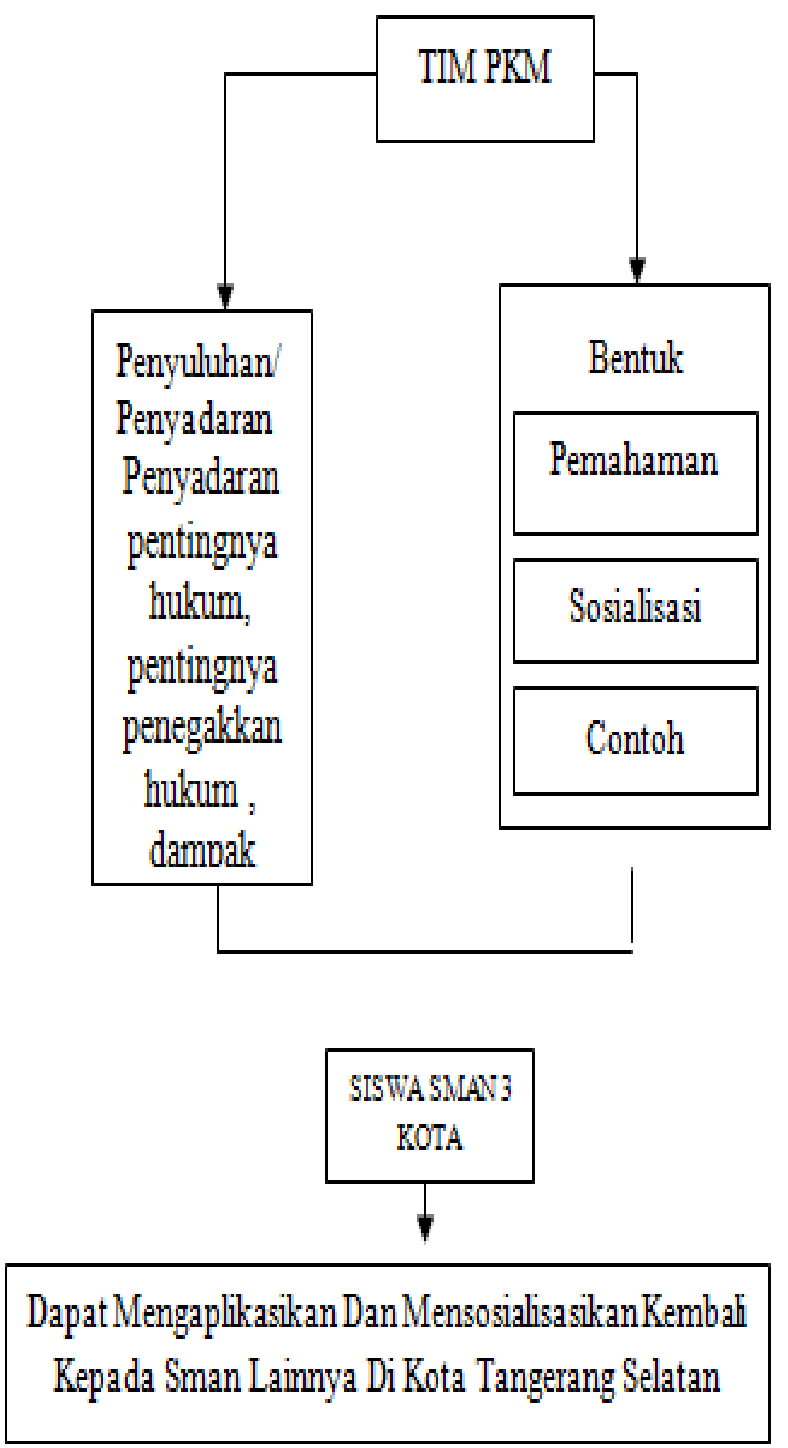

\section{Gambar 1}

\section{Alur Kegiatan Pengabdian Masyarakat}

menegakkan norma hukum sebagai arahan untuk berperilaku dalam tatanan kehidupan sosial atau hubungan hukum dalam 
kehidupan publik dan negara. Dalam arti lain, proses penegakan hukum melibatkan semua aktor hukum dalam setiap hubungan hukum. Siapa pun yang melakukan aturan normatif atau melakukan sesuatu atau tidak melakukan sesuatu berdasarkan norma hukum yang berlaku berarti ia menegakkan atau menegakkan aturan hukum.

Penegakan hukum hanya ditafsirkan sebagai upaya oleh lembaga penegak hukum tertentu untuk menjamin dan memastikan bahwa aturan hukum berjalan sebagaimana mestinya. Penegakan hukum juga dapat dilihat dari sudut pandang objek, yaitu dari segi hukum. Dalam hal ini, maknanya juga mencakup makna luas dan sempit. Dalam arti luas, penegakan hukum mencakup nilainilai keadilan yang terkandung dalam suara aturan formal dan nilai-nilai keadilan yang hidup dalam masyarakat. Namun, dalam arti

Sumber hukum terdiri dari sumber hukum tertulis serta tidak tertulis. Sumber hukum dasar nasional adalah Pancasila tertuang serta tertulis didalam Pembukan. Undang-Undang Dasar 1945, yaitu Tuhan Yang Maha Esa, Kemanusiaan yang adil dan beradab, Persatuan Indonesia, dan kerakyatan yang dipimpin oleh kebijaksanaan dalam musyawarah /perwakilan, dan dengan mewujudkan keadilan sosial bagi seluruh rakyat Indonesia. Berdasarkan berbagai pemaparan penyuluhan dapat dimaknai bahwa aturan sempit, penegakan hukum hanya menyangkut peraturan formal dan tertulis.

Aturan hukum di Indonesia diuraikan dalam konstitusi Negara yaitu UndangUndang Dasar 1945. UUD 1945 merupakan dasar hukum Negara yang menduduki hukum tertinggi dalam tatanan hukum Indonesia. Di bawah UUD 1945 ada berbagai aturan hukum atau legislasi yang bersumber dari UUD 1945. Perintah hukum adalah rangkaian sistem hukum yang saling terintegrasi yang diatur secara tertib di Indonesia sebagaimana diatur dalam Keputusan MPR No.III /MPR/ 2000 tentang Sumber Hukum dan Tata Tertib. Dalam ketentuan ini dinyatakan bahwa yang dimaksud dengan sumber dari hukum adalah sumber yang dapat dijadikan bahan untuk merumuskan perundang-undangan.

hukum yang ada di Indonesia wajib untuk diketahui oleh peserta didik, sebagai generasi muda tentunya butuh pengetahuan lebih tentang aturan hukum tersebut serta dapat diimplementasikan dalam kehidupan seharihari. 


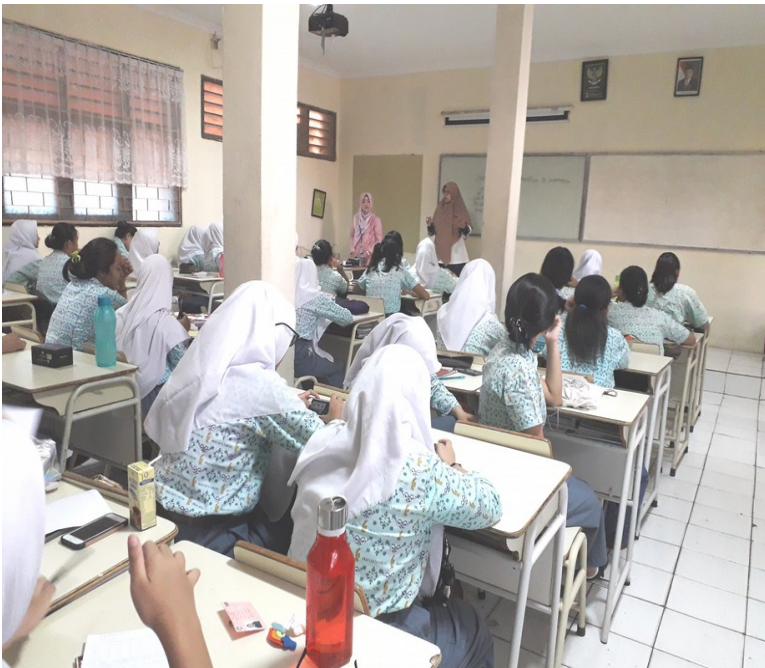

Gambar 2

\section{Pelaksanaan Penyuluhan}

Hasil dari pengabdian masyarakat ini, dapat dilihat dari antusias siswa-siswi SMA Negeri 3 Tangerang Selatan untuk bertanya tentang aturan hukum yang ada di Indonesia. Tim Dosen PKM menjawab berbagai pertanyaan siswa yang sangat kritis terhadap permasalahan hukum yang ada. Tim Dosen PKM memberikan edukasi kepada peserta didik tentang dampak pelanggaran hukum yang terjadi serta implementasi penegakkan hukum yang ada dilingkungan sekitar siswa, mulai dari di lingkungan keluarga sampai di lingkungan sekolah sampai masyarakat. Salah satu upaya penegakkan hukum yang dapat dilakukan siswa di sekolah yaitu mentaati tata tertib yang berlaku di sekolah.

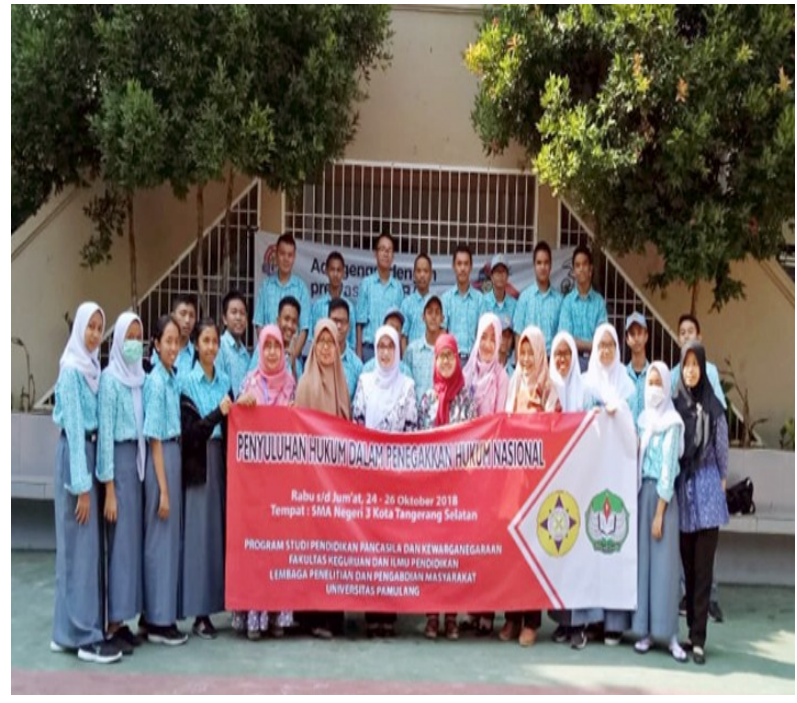

Gambar 3

Tim Dosen PKM bersama Siswa dan Guru

Berdasarkan hasil pengabdian masyarakat ini juga dapat dilihat terdapat peningkatan kesadaran peserta didik terhadap hukum di Indonesia. Hal ini dapat dibuktikan berdasarkan hasil wawancara dengan siswasiswi SMA Negeri 3 Tangerang Selatan yang menyatakan bahwa kegiatan pengabdian ini dapat menambah pengetahuan mereka terkait dengan hukum di Indonesia, karena selama ini siswa mengetahui hukum hanya terkait dengan materi dalam pembelajaran Pendidikan Kewarganegaraan saja. Sehingga dengan pemaparan yang disampaikan narasumber dalam pengabdian masyarakat ini dapat menambah informasi dan wawasan siswa terkait dengan penegakkan hukum di Indonesia.

Kelebihan dari kegiatan pengabdian ini yaitu dapat menambah pengetahuan baru bagi peserta didik terkait dengan aturan 
hukum di Indonesia yang tidak bisa peserta didik dapatkan dalam pelajaran. Kegiatan pengabdian masyarakat ini tentunya masih terdapat banyak kekurangan yang harus diperbaiki untuk dilaksanakan kedepannya, terutama dalam hal kerjasama dengan pihakpihak aparat yang berwenang untuk dapat bersama-sama mensosialisasikan aturan hukum bagi peserta didik.

Implikasi dari kegiatan pengabdian kepada masyarakat ini adalah memberikan kontribusi nyata terhadap penegakkan hukum di Indonesia yang wajib ditegakkan demi terwujudnya rasa keadilan sosial bagi seluruh rakyat Indonesia. Penegakkan hukum di masyarakat dapat dilakukan di lingkungan sekolah, sekolah sebagai lembaga sosial yang sangat penting dalam menciptakan generasi penerus bangsa yang taat pada aturan hukum baik yang ada di sekolah maupun masyarakat sehingga dengan pembiasaan terhadap aturan hukum maka peserta didik dapat mengimplementasikan dalam kehidupan sehari-hari. Hukum menjadi panduan kehidupan sehingga nantinya peserta didik dapat menjadi warga negara yang baik.

Solusi yang dapat Tim dosen tawarkan dalam kegiatan pengabdian masyarakat ini yaitu adanya kerjasama intensif antara Universitas Pamulang dengan SMA Negeri 3 Tangerang Selatan untuk mendampingi siswa terkait dengan sosialisasi hukum di Indonesia, sehingga kedepannya
SMA Negeri 3 Tangerang Selatan dapat menjalin kerjasama tidak hanya dari pihak kampus, tetapi juga menjalin kerjasama pada lembaga-lembaga sosial lainnya. Sehingga dengan menjalin kerjasama yang baik dengan berbagai pihka diharapkan dapat menjadi peserta didik yang memiliki rasa tanggung jawab yang penuh agar dapat mematuhi aturan hukum dilingkungan sekitarmya dan ketika ada ada permasalahan yang terjadi dalam dilingkungan sekolah baik yang dilakukan guru maupun siswa yang terkait dengan pelanggaran hukum, maka dapat dipecahkan sesuai dengan aturan hukum yang ada.

\section{KESIMPULAN}

Bangsa Indonesia merupakan negara hukum, perlu adanya sosialisasi untuk dapat menegakkan hukum di Indonesia. Hukum sebagai panduan untuk berprilaku dalam kehidupan sosial. Aturan hukum Indonesia didasarkan pada Pancasila, UUD 1945, serta peraturan hukum lainnya. Pada pengabdian ini menggunakan metode penyuluhan dan penyadaran hukum kepada siswa-siswi SMA Negeri 3 Tangerang Selatan. Hasil dari pengabdian masyarakat ini, dapat dilihat dari antusias siswa-siswi SMA Negeri 3 Tangerang Selatan untuk bertanya tentang aturan hukum yang ada di Indonesia, sehingga dari pengabdian ini didapatkan adanya peningkatan kesadaran peserta didik 
untuk menegakkan hukum baik di hukum. Atas dukungan dan partisipasi semua lingkungan sekolah maupun rumah. pihak, kami ucapkan terima kasih.

Implikasi dari kegiatan pengabdian kepada masyarakat ini adalah memberikan kontribusi nyata terhadap penegakkan hukum di Indonesia yang wajib ditegakkan demi terwujudnya rasa keadilan sosial bagi seluruh rakyat Indonesia. Saran kepada pihak sekolah agar melibatkan peserta didik secara langsung untuk menegakan aturan hukum di sekolah maupun masyarakat.

\section{REFERENSI}

Hariadi, Pramono dkk. (2011). Materi dan Pembelajaran PKN SD. Jakarta: Universitas Tebuka.

Suparmin, dkk. (2013). Sistem Dan Peradilan Nasional Di Indonesia. Solo : Mediatama.

Pengabdian kepada Masyarakat yang telah dilaksanakan semoga dapat memberikan kontribusi nyata dalam bidang Soegito, dkk. (2017). Pendidikan Pancasila. Semarang : UPT UNNES Press.

Soekanto, Soerjono. (1983) Faktor-faktor Yang Mempengaruhi Penegakan Hukum. Jakarta: UI Press. 